\title{
ГОСПОДАРСЬКЕ ПРАВО
}

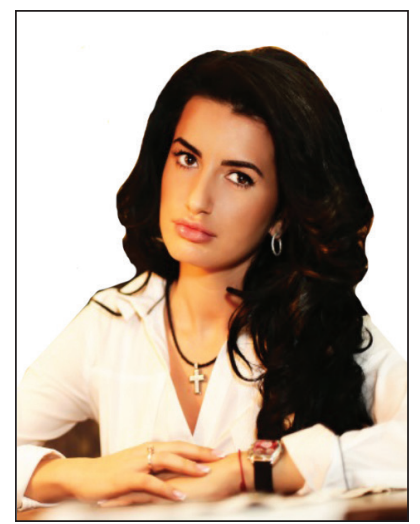

Остапенко Юлія Ігорівна, кандидат юридичних наук, асистентка кафедри господарського права, Начіональний юридичний університет імені Ярослава Мудрого, Україна, м. Харків e-mail:julost@ukr.net ORCID 0000-0002-4033-5927

doi: 10.21564/2414-990x.142.143545

YAK 346.13.(094)

\section{ПРОЦЕС АААПТАЦІЇ ГОСПОААРСЬКОГО ЗАКОНОААВСТВА УКРАЇНИ: НАПРЯМИ I ПЕРСПЕКТИВИ}

Досліджено поняття-тренд сучасного законотворчого процесу - «адаптація». Особливу увагу приділено адаптаціі господарського законодавства і приведення його у відповідність до стандартів правового регулювання господарських відносин більш розвинених країн. Доведено необхідність унесення кардинальних змін у вітчизняне господарське законодавство, а також охарактеризовано модифікації відповідного прочесу. Встановлено важливі напрями реформування господарсько-правового механізму.

Ключові слова: господарське законодавство України; адаптація законодавства; законотворча діяльність; імплементація; експертиза новел адаптаційного характеру.

Остапенко Ю. И., кандидат юридических наук, ассистентка кафедры хозяйственного права, Национальный юридический университет имени Ярослава Мудрого, Украина, г. Харьков.

e-mail : julost@ukr.net ; ORCID 0000-0002-4033-5927

Адаптационные процессы розвития хозяйственного законодательства Украины

В статье исследуется понятие-тренд современного законотворческого процесса - «адаптация». Особое внимание в статье уделено процессу адаптащии законодательства к более развитым стандартам правового регулирования хозяйственных отношений, а также охарактеризованы модификащии соответствующего прощесса. Установлены глобальные законодательные изменения в контексте прочессов адаптации в хозяйственном законодательстве, подчеркиваются важные аспекты в реформировании хозяйственно-правового механизма.

Ключевые слова: хозяйственное законодательство Украины; адаптация законодательства; законотворческая деятельность; имплементация законодательства; экспертиза новелл адаптационного характера. 
Постановка проблеми. Сучасне життя суспільства й держави є динамічним, що, звісно, позначається на функціонуванні іх інститутів. За таких умов будь-яка галузь права (законодавства) як система загальновизнаних, формально визначених й обов'язкових правил поведінки найбільш ефективно виконує свою головну функцію універсального регулятора суспільних відносин лише тоді, коли у процесі правотворчості, а особливо правореалізації, враховуються специфіка і зміст тих відносин, що становлять ï предмет і регламентуються приписами певних актів. Крім того, якщо відповідні суб'єкти правотворчості оперативно реагують на еволюційні, прогресивні зміни, що відбуваються у суспільстві, і приводять правові норми у відповідність до них, законодавство сприймається широким загалом як певна соціальна цінність [1, с. 47].

До цього варто додати, що в сучасному світі розвиток національних економік стає все більшою мірою залежним (з огляду на те, що тісно пов'язаний) від процесів глобалізації. 3 певною умовністю нині можна вести мову й про створення, так би мовити, світової, або глобальної економіки, що суттєво впливає як на національні економіки, так і відносини, зокрема, інвестиційні, експортно-імпортні тощо. Крім того, сьогодні тенденцією світового прогресу й одночасно передумовою подальшої інтенсифікації процесів глобалізації розвитку світового господарства $є$ інтеграція [2, с. 47]. У цьому контексті доречно навести висловлювання А. Губи стосовно того, що зараз на передові позиції виходить економічна інтеграція - процес розвитку глибоких, стійких взаємозв'язків і поділу праці між національними господарствами, створення міжнародних господарських комплексів у межах держави, а також зближення та взаємодія національних економік [3, с. 47]. У той же час слід пам'ятати, що інтеграції, у тому числі й економічній як ії складовій, властиві динамічність, складність і суперечливість, а це має особливе значення, оскільки від усвідомлення останнього залежить те, яким чином й в якому напрямі проводити, якщо потрібно, оновлення національного законодавства задля узгодження його приписів і норм міжнародного права і визначення форм їх взаємного впливу один на одного. Отже, нині актуальним стає дослідження й аналіз цих явищ, оскільки завдяки цьому з'явиться можливість всебічно вивчити динаміку економічних взаємовідносин між країнами в умовах глобалізації, з огляду на що вдасться вирішити й проблеми адаптації національного, зокрема господарського, законодавства і приведення його у відповідність до європейського.

3 огляду на наведене додамо, що наразі виникає необхідність організаційної інституалізації адаптаційного механізму в системі національних законотворчих процесів, що має стати їх постійною складовою. Це необхідно передусім для створення наукового і методологічного підгрунтя (забезпечення) процесу розвитку економіки й окремих іiї секторів, через формування відповідних сегментів «адаптаційного» господарського законодавства України.

Аналіз останніх досліджень $і$ публікацій. Поняття «адаптація законодавства» аналізували у своїх працях переважно представники теорії держави і права та юристи-міжнародники, серед яких слід назвати роботи Т. М. Ана- 
кіної, М. М. Гнатовського, М. М. Микієвича, В. І. Муравйова, Р. А. Петрова, О. І. Головко-Гавришевої, О. М. Лисенко, О. В. Святуна, І. В. Суходубової, О. Я. Трагнюк, О. М. Шпаковича, І. В. Яковюка. Господарсько-правові аспекти частково розглядали такі вчені-господарники, як О. М. Вінник, Д. В. Задихайло, Г. Л. Знаменський, В. К. Мамутов, О. І. Миколенко, В. І. Муравйов, К. О. Стаднік, О. В. Шаповалова та ін. Отже, наявність чималої кількості відповідних наукових напрацювань дозволяє сформувати універсальну теоретичну матрицю для подальшого дослідження відповідного законодавчого феномену, який є важливим з точки зору не тільки отримання новітніх науково-теоретичних результатів, а й для підвищення якості реформ, що проводяться чи будуть проведені в усіх сферах господарювання.

Метою статmi є дослідження особливостей адаптаційних процесів, що нині відбуваються в національному законодавстві, встановлення їх практичного значення для підвищення ефективності господарського законодавства, повноти й системності його регулятивного впливу на сферу господарювання i, як наслідок, виконання регулятивно-динамічної його функції.

Виклад основного матеріалу. Як стверджують учені, протягом багатьох десятиліть суспільні економічні процеси у світі розвивалися під впливом інтеграційних, які охопили майже всі регіони земної кулі і встановили «єдині правила гри» на економічному «майданчику» [4, с. 5]. Звісно, інтеграція у тій чи іншій частині світу відбувається за різних соціально-економічних і політико-правових умов. Невід'ємною складовою загального інтеграційного економічного процесу є правова інтеграція, тобто встановлення «єдиних правил гри», що передбачають поступове зближення і гармонізацію національних правових систем.

Україна, позиціонуючи себе як європейська країна, після проголошення незалежності шукає власне місце, долучаючись до світових інтеграційних процесів. Як свідчить практика, останні проходять декілька етапів: від створення умов для вільної торгівлі до координації і узгодження країнами напрямів своєї політики у різних галузях [5, с. 5]. I хоча кількість інтеграційних організацій, заснованих для управління цими процесами, постійно збільшується, однак тільки такі організації, як Європейський Союз (далі - ЄС) та СОТ досягли високого рівня інтеграції. Нині ж перед країнами-членами постало питання, яким чином і в яких напрямах проводити економічну, зовнішню й внутрішню політику, переслідуючи при цьому спільні цілі. Це є свідченням того, що певні адаптаційні процеси тривають, а нашій державі необхідно передусім національне законодавство привести у відповідність до норм та стандартів, установлених і сприйнятих відповідними європейськими спільнотами.

Слушно розгляд будь-якого питання починати із вивчення понятійного апарату. Поняттям «адаптація законодавства» (від лат. adapto - «пристосування», «прилаштування») позначають процес приведення нормативно-правових актів певної держави у відповідність до обраного стандарту. Спираючись на наведене, можемо зробити висновок про те, що країна «адаптант» повинна узгодити вну- 
трішні стандарти і приписи, закріплені в нормах національного законодавства, із стандартами тих країн-адаптації (союзів країн-адаптації), політику яких вона обирає як взірець, орієнтир. Національні інтереси сучасної України, звісно, тісно пов’язані з євроінтеграцією, серед головних завдань якої зазначено й таке, як адаптація українського законодавства, особливо економічного, до міжнародних європейських стандартів, тобто досягнення певного рівня узгодженості вітчизняної нормативної бази із європейською, тобто приведення у відповідність законодавства України до стандартів права ЄС та СОТ [6, с. 10]. Це передусім необхідно з огляду на розширення і поглиблення виробничо-технологічних зв’язків, спільне використання ресурсів, об’єднання капіталів, взаємне бажання і прагнення до створення сприятливих умов для проведення економічної діяльності, зняття взаємних бар'єрів [7, с. 138]. Крім того, інтеграція як процес передбачає створення поглибленої і всеосяжної зони вільної торгівлі, котрій притаманні деякі риси спільного ринку [8, с. 57; 9, с. 247].

Приємно, що наша держава поступово, крок за кроком просувається вперед. Так, із метою інституційного забезпечення процесу адаптації законодавства України до законодавства ЄC та СОТ Постановою Кабінету Міністрів України «Про затвердження Положення про Міжвідомчу координаційну раду з адаптації законодавства України до законодавства Європейського» від 12.11.1998 р. № 1773 було засновано Міжвідомчу координаційну раду. Примітно, що іï найважливішими завданнями визначено координацію діяльності міністерств, інших центральних і місцевих органів виконавчої влади у забезпеченні адаптації законодавства України до законодавства $\mathrm{CC}$; вироблення пропозицій щодо стратегії адаптації законодавства України до норм і стандартів СС; розроблення рекомендацій до проектів законів, інших нормативно-правових актів щодо реалізації положень Угоди про партнерство і співробітництво між ЄС та Україною, забезпечення виконання приписів основних документів Ради з питань співробітництва між Україною та ЄС тощо. Крім того, у 1999 р. Президент України видав Указ № 145/99 «Про заходи щодо вдосконалення нормотворчої діяльності органів виконавчої влади», згідно з яким Кабінет Міністрів України запровадив єдину систему планування, координації й контролю нормотворчої діяльності і роботи органів виконавчої влади з адаптації законодавства. Відповідно до цього Указу на Міністерство юстиції України було покладено обов’язок із планування цієї роботи і контролю за їі здійсненням.

Таким чином, процес зближення українського законодавства із сучасною європейською економічною системою права розпочався і триває, що дасть змогу підприємницькій, зовнішньоекономічній, торговельній, науково-технічній діяльності та іншим ㅃï видам розвиватися відповідно до встановлених стандартів. У контексті сказаного треба підкреслити, що сам процес адаптації законодавства України до «європрава» полягає в поетапному ухваленні й впровадженні відповідних законів і підзаконних нормативно-правових актів України, розроблених з урахуванням права Європейського Союзу та СОТ, також у внесенні певних змін до чинних правових актів України, а також мож- 
ливості проведення пакетних змін певного сектору в економіці. Вбачається за доцільне проілюструвати відповідні процеси на прикладі аграрного сектору економіки. Так, підписавши 14.07.1994 р. Угоду «Про партнерство та співробітництво з Європейськими співтовариствами» (даний тип угод ЄС використовує для оформлення своїх відносин з усіма країнами СНД), Україна взяла на себе зобов’язання щодо модернізації й приватизації аграрного сектору економіки, розвитку внутрішнього й зовнішнього ринків для українських товарів за умови забезпечення охорони навколишнього природного середовища й підвищення безпеки продуктів харчування [10, с. 247]. Крім того, зобов’язалася поступово наближувати українські стандарти стосовно продуктів харчування, включаючи санітарні й фітосанітарні, до технічних правил СС. Як наслідок, упродовж наступних декількох років з'явилися численні нормативні акти, спрямовані на виконання взятих зобов’язань. Зокрема, у 1998 р. Указом Президента України затверджено Стратегію інтеграції України в СС, яка передбачає адаптацію законодавства, наближення до сучасної європейської системи права; 1999 р. Кабінет Міністрів України схвалив Концепцію, яка закріпила основні етапи й механізм даного процесу, а також Тимчасовий регламент, у якому передбачено механізм моніторингу проектів нормативних актів, розроблених центральними органами виконавчої влади, щодо їх відповідності законодавству ЄС, а Законом України «Про Загальнодержавну програму адаптації законодавства України до законодавства Європейського Союзу» від 18.03.2004 p. № 1629-15 затверджено Загальнодержавну програму адаптації законодавства України до законодавства ЄC, яка визначає основні напрямки й етапи адаптації до кінця 2007 р. Як видно з перелічених документів, із підписанням міжнародної угоди український законодавець повинен був переглянути (адаптувати) національне законодавство поступово, тобто у відповідному секторі економіки пакетом, але окремо.

Враховуючи наведене, додамо, що адаптація законодавства може носити не тільки загальний (адаптація права СОТ за окремими економічними секторами, пакетна адаптація), а й приватний характер, тобто адаптація (інтернаціоналізація) світового тренду законодавства. Прикладом цього є Закон України «Про акціонерні товариства» від 11.06.2017 р. № 514-17, який був оновлений (тобто відбулася адаптація й узгодження його приписів із європейськими) відповідно до Закону України «Про ратифікацію Угоди про асоціацію між Україною, з однієї сторони, та Європейським Союзом, Європейським співтовариством з атомної енергії і їх державами-членами, з іншої сторони» від 16.09.2014 p. №1678-VII. Майже одночасно, точніше 30 вересня, Генеральний секретаріат Ради ЄС вербальною нотою встановив, що починаючи з 01.11.2014 р. буде тимчасово застосовуватися частина розділів і додатків Угоди про асоціацію. Серед них додатки XXXIII та XXXV до глави 13 «Законодавство про заснування і діяльність компаній, корпоративне управління та бухгалтерський облік та аудит», які торкаються питань корпоративного управління - діяльності акціонерних товариств, товариств із обмеженою відповідальністю, розкриття інформації про юридичних осіб, а також питань поглинання, злиття й поділу 
АТ тощо. Строк, відведений Угодою про асоціацію на приведення українського законодавства щодо корпоративного управління й захисту прав акціонерів у відповідність до права СС, від 2 до 4 років, звісно, починаючи з 01.11.2014 p. Варто відмітити, що із врахуванням того, що гармонізація законодавства України з правом ЄС була розпочата ще у 1994 р., після підписання Україною Угоди про партнерство та співробітництво з Свропейськими співтовариствами та їх державами-членами, наше корпоративне законодавство вже частково узгоджене iз директивами $\mathrm{CC}$. Серед директив, положення яких потребують імплементації в корпоративне законодавство України, слід виокремити Другу Директиву ЄС 77/91/ЕЄС від 13.12.1976 р. про створення АТ і зміну розміру статутного капіталу АТ, Третю Директиву № 78/855/ЕСС від 9.10.1978 р. про злиття АТ, Шосту Директиву № 82/891/ЕЄС від 17.12.1982 р. про поділ АТ та Тринадцяту Директиву № 2004/25/ЄС від 21.12.1989 р. про поглинання АТ.

Для повноти висвітлення питання вбачається за доцільне розглянути й такі види адаптації законодавства, як зовнішня (тобто адаптація законодавства (держави-реципієнта чи адаптанта) до міжнародних угод (донорської правової системи), прикладом є СОТ) і внутрішня (адаптація законів до кодексу чи адаптація закону до закону, прийнятого пізніше за часом). Як приклад, можемо навести адаптацію Закону України «Про господарські товариства» від 19.09.1991 р. № 1577-XII до Цивільного і Господарського кодексів України, Законів України «Про акціонерні товариства» від 17.09.2008 р. № 514-17, «Про державне регулювання ринку цінних паперів в Україні» від 30.10.1996 р. № 475/96 тощо. Зокрема, відповідно до розділу XVII «Прикінцеві та перехідні положення» вказаного Закону, а саме п. 2 «Через два роки з дня набрання чинності цим Законом втрачають чинність статті 1-49 Закону України «Про господарські товариства»». Крім того, п. 3 передбачається: «внести зміни до таких законодавчих актів України: 1) у Цивільному кодексі України: в абз. 1 ч. 2 ст. 110 слова «а також учасником юридичної особи» замінити словами «учасником юридичної особи, а щодо акціонерних товариств - також Державною комісією 3 цінних паперів та фондового ринку»; у ст. 152: ч. 1 викласти в такій редакції: «1. Акціонерне товариство - господарське товариство, статутний капітал якого поділено на визначену кількість часток однакової номінальної вартості, корпоративні права за якими посвідчуються акціями»; у частині п'ятій слова «проводить відкриту підписку на акції» замінити словами «здійснює публічне розміщення акцій»; доповнити частиною шостою такого змісту: «6. Акціонерні товариства за типом поділяються на публічні товариства та приватні товариства. Особливості правового статусу публічних та приватних акціонерних товариств встановлюються законом»; ч. 1 ст. 153 доповнити словами «а також державою в особі уповноваженого органу, територіальною громадою в особі уповноваженого органу» тощо; 2) у Господарському кодексі України: ст. 81 виключити; у першому реченні ч. 4 ст. 87 слова «двадцять п’ять» замінити словом «п'ятнадцять»; у першому реченні абз. 4 ч. 1 ст. 88 слова «про діяльність товариства» замінити словами «про товариство»; 3) п. 23 ч. 2 ст. 7 Закону України «Про 
державне регулювання ринку цінних паперів в Україні» доповнити словами «та акціонерні товариства» тощо.

Однак адаптація законодавства є окремим випадком правової інтеграції і виявом діалогу правових культур. Спираючись на дослідження С. В. Грищака [11, с. 274], можна виокремити ще й такі форми адаптації законодавства:

1) апроксимація (лат. approximare - «наближення»), тобто процес прийняття, внесення змін чи скасування правових норм із метою наближення положень національного законодавства до положень актів законодавства іншої держави, групи держав або міжнародної спільноти загалом;

2) імплементація (лат. impleo - «наповнення», «виконання») - правотворча діяльність держави з метою реалізації прийнятих відповідно до міжнародного права зобов’язань;

3) транспозиція (лат. trānspositiō - «перекладання») означає процес прийняття, внесення змін чи скасування правових норм із метою досягнення ідентичності з відповідними донорськими актами. Транспозиція може також означати копіювання тексту законодавчого документа дослівно в національне законодавство або пряме посилання на міжнародний акт у національному законодавстві;

4) координація (лат. coordinatio - взаємне впорядкування), тобто процес узгодження тієї частини національного законодавства та практики його застосування, щодо якої наближення або транспозиція є неможливими або непотрібними.

Варто додати, що майже всі вищеназвані процеси в нашій країні розпочато. Завдання одне - прискоритися і довести до логічного кінця, що сприятиме сталому розвитку держави, економіки і господарства.

Висновки. Підсумовуючи, можемо констатувати наступне.

1. Необхідною є організаційна інституалізація адаптаційного механізму в системі національних законотворчих процесів, яка має стати їх постійною складовою. Це передусім потрібно і для кваліфікованого методологічно забезпеченого процесу розвитку економіки в цілому і окремих iㅣ секторів через формування відповідних сегментів «адаптаційного» господарського законодавства України.

2. Процеси адаптації вітчизняного господарського законодавства до більш досконалих стандартів господарсько-правового регулювання розвинених країн, зокрема Заходу, мають співвідноситися з реальним станом розвитку господарських відносин в Україні. Крім того, він має виконувати регулятивно-динамічну функцію права, у тому числі господарського, але при цьому не можуть запроваджуватися конструкції, які зависають у цілковитому вакуумі суспільних відносин.

3. Шоб здійснити вибір об’єкта адаптації, слід встановити спорідненість моделі розвитку відповідного сегмента ринкової економіки або типу державного регулювання економічних (господарських) відносин, адже, як відомо, економічні відносини у США і ФРН мають суттєві відмінності щодо господар- 
сько-правових механізмів їх реалізації. Класичним й ідеальним варіантом має бути концептуальна (стратегічна) визначеність держави щодо змісту і напрямів розвитку відповідного власного сектора національної економіки. Враховуючи все це, методологією розробки концептуальних документів держави має бути передбачено обов'язкову вказівку на ту модель економічних відносин, що є для нас референтною. Звісно, тоді пошук законодавчих стандартів правового регулювання набуває визначеності і отримує цілеспрямований та послідовний характер.

4. Адаптація повинна стати не тільки елементом законотворчого процесу, а й складовою господарсько-правової політики, тобто закласти основи процесу інституалізації механізмів формування і здійснення алгоритмів застосування правових засобів державного впливу на зміст, структуру й динаміку внутрішньо- та зовнішньоекономічних відносин, макроекономічні властивості ринкової рівноваги, шляхом відповідної корекції змісту (досягнення узгодженості і відповідності змісту правового господарського порядку країни-адаптатора. Отож, усі дослідження у сфері господарського права повинні як один з елементів мети включати встановлення доцільності запозичення тих чи інших зарубіжних конструкцій чи механізмів, рівня їх життєздатності й перспективності в національній правовій системі координат.

\section{Список літератури:}

1. Суходубова I. В. Стабільність і динамізм законодавства: поняття, співвідношення, засоби забезпечення : монографія / наук. ред. О. В. Петришин. Харків : Право, 2016. 228 с.

2. Місяць Т. Проблеми теорії та методології бухгалтерського обліку, контролю і аналізу. Міжнародний збірник наукових пращь. Серія: Бухгалтерський облік, контроль і аналіз. Вип. 3 (15) / відп. ред. д.е.н., проф. Ф. Ф. Бутинець. Житомир : ЖДТУ, 2009. С. 185-192.

3. Губа А. В. Вплив процесів економічної інтеграції на соціально-економічний розвиток країн. Формування ринкових відносин в Україні. 2012. № 6. С. 67-70.

4. Свропейське право: право Свропейського Союзу : підручник / за заг. ред. В. І. Муравйова. Київ : Ін Юре, 2015. 312 с.

5. Федун М. Адаптація законодавства України до стандартів Свропейського Союзу у сфері поводження з відходами. Вісник Львівського університету. Серія: Міжнародні відносини. 2014. № 36, ч. 2. С. 191-199.

6. Яковюк I. В. Адаптація законодавства України до законодавства Свропейського Союзу: проблеми теорії і практики. Свропейсъкий Союз і Україна: особливості взаємовідносин на сучасному етапі / Нац. акад. прав. наук України, НДІ держ. буд-ва та місц. самоврядування. Харків : Оберіг, 2012. Розд. 1. С. 5-47. (Серія «Наукові доповіді» ; вип. 1).

7. Райзберг Б. А., Лозовской Л. Ш., Стародубцева Е. Б. Современный экономический словарь. 2-е изд., испр. Москва : ИНФРА-М, 1999. 479 с.

8. Анакіна Т. М. Особливості політики Східного партнерства у контексті європейської інтеграції України. Європейський Союз і Україна: особливості взаємовідносин на сучасному етапі / Нац. акад. прав. наук України, НДІ держ. буд-ва та місц. самоврядування. Харків : Оберіг, 2012. Розд. 2. С. 48-61. (Серія «Наукові доповіді» ; вип. 1).

9. Стадник К. О Модернізація господарського законодавства України щодо економічної концентрації в контексті євроінтеграції. Вісник Національного університету «Юридична академія України імені Ярослава Мудрого». Серія: Економічна теорія та право. 2013. № 4. С. 246-253.

10. Статівка А. М., Шуміло I. А. Про адаптацію аграрного законодавства України до законодавства Європейського Союзу. Проблеми законності. 2009. Вип. 100. С. 207-217. 
11. Грищак С. В. Теоретичні основи адаптації законодавства України до законодавства Європейського Союзу. Форум права. 2012. № 4. С. 273-277. URL: http://nbuv.gov.ua/UJRN/ FP_index.

\section{References:}

1. Sukhodubova, I.V. (2016). Stabilnist i dynamizm zakonodavstva: poniattia, spivvidnoshennia, zasoby zabezpechennia. O.V. Petryshyn (Ed.). Kharkiv: Pravo [in Ukrainian].

2. Misiats, T. (2009). Problemy teorii ta metodolohii bukhhalterskoho obliku, kontroliu i analizu. Mizhnarodnyi zbirnyk naukovykh prats. Seriia: Bukhhalterskyi oblik, kontrol i analiz, issue 3 (15). F.F. Butynets (Ed.). Zhytomyr: ZhDTU, 185-192 [in Ukrainian].

3. Huba, A.V. (2012). Vplyv protsesiv ekonomichnoi intehratsii na sotsialno-ekonomichnyi rozvytok krain. Formuvannia rynkovykh vidnosyn v Ukraini, 6, 67-70 [in Ukrainian].

4. Yevropeiske pravo: pravo Yevropeiskoho soiuzu. V.I. Muraviov (Ed.). (2015). Kyiv: In Yure [in Ukrainian].

5. Fedun, M. (2014). Adaptatsiia zakonodavstva Ukrainy do standartiv Yevropeiskoho Soiuzu u sferi povodzhennia z vidkhodamy. Visnyk Lvivskoho universytetu. Seriia: Mizhnarodni vidnosyny, 36, ch. 2, 191-199 [in Ukrainian].

6. Yakoviuk, I.V. (2012). Adaptatsiia zakonodavstva Ukrainy do zakonodavstva Yevropeiskoho Soiuzu: problemy teorii i praktyky. Yevropeiskyi Soiuz i Ukraina: osoblyvosti vzaiemovidnosyn na suchasnomu etapi; Nats. akad. prav. nauk Ukrainy, NDI derzh. bud-va ta mists. samovriaduvannia. Kharkiv: Oberih, ch. 1, 5-47 [in Ukrainian].

7. Rajzberg, B.A., Lozovskoj, L.Sh., Starodubceva, E.B. (1999). Sovremennyj jekonomicheskij slovar'. Moscow: INFRA-M [in Russian].

8. Anakina, T.M. (2012). Osoblyvosti polityky Skhidnoho partnerstva u konteksti yevropeiskoi intehratsii Ukrainy. Yevropeiskyi Soiuz i Ukraina: osoblyvosti vzaiemovidnosyn na suchasnomu etapi; Nats. akad. prav. nauk Ukrainy, NDI derzh. bud-va ta mists. samovriaduvannia. Kharkiv: Oberih, ch. 2, 48-61 [in Ukrainian].

9. Stadnyk, K.O. (2013). Modernizatsiia hospodarskoho zakonodavstva ukrainy shchodo ekonomichnoi kontsentratsii v konteksti yevrointehratsii. Visnyk Natsionalnoho universytetu «Iurydychna akademiia Ukrainy imeni Yaroslava Mudroho». Seriia: Ekonomichna teoriia ta pravo, 4, 246-253 [in Ukrainian].

10. Stativka, A.M., Shumilo, I.A. (2009). Pro adaptatsiiu ahrarnoho zakonodavstva Ukrainy do zakonodavstva Yevropeiskoho Soiuzu. Problemy zakonnosti - Problems of Legality, issue 100, $207-217$ [in Ukrainian].

11. Hryshchak, S.V. (2012). Teoretychni osnovy adaptatsii zakonodavstva Ukrainy do zakonodavstva Yevropeiskoho Soiuzu. Forum prava, 4, 273-277. URL: http://nbuv.gov.ua/UJRN/ FP_index [in Ukrainian].

Ostapenko Y. I., PhD in Law, Assistant of the Department of Economic Law, Yaroslav Mydryi National Law University, Ukraine, Kharkiv.

e-mail : julost@ukr.net ; ORCID 0000-0002-4033-5927

\section{Process of adaptation of economic legislation of Ukraine: directions and prospects}

The article explores the concept-trend of the modern legislative process - «adaptation». Particular attention is paid in the article to the process of adaptation of legislation to more developed standards of legal regulation of economic relations, and also modifications of the corresponding process are characterized. Global legislative changes have been established in the context of adaptation processes in economic legislation, important aspects in the reform of the economic and legal mechanism are underlined.

The processes of adaptation of domestic economic legislation to more perfect standards of economic regulation of developed countries, in particular the West, must be correlated with the real state of development of economic relations in Ukraine. In addition, he has to perform the regulatory-dynamic 
function of lare, including economic, but at the same time can not be implemented designs that hang in the complete vacuum of social relations.

Adaptation should become not only an element of the lawmaking process, but also an integral part of economic and legal policy, that is to lay the foundations of the process of institutionalization of mechanisms for the formation and implementation of algorithms for the application of legal means of state influence on the content, structure and dynamics of internal and external economic relations, macroeconomic properties of market equilibrium, appropriate correction of the content (achievement of consistency and compliance of the contents of the legal economic order of the country-adaptor. Therefore, all researches ting in commercial law should as part of goals include establishing feasibility of drawing certain foreign structures or mechanisms of their viability and prospects of the national legal system of coordinates.

Keywords: economic legislation of Ukraine; adaptation of legislation; law-making activity; implementation of legislation; the examination of adaptive novels.

Надійшла до редколегіï 01.05.2018 р. 